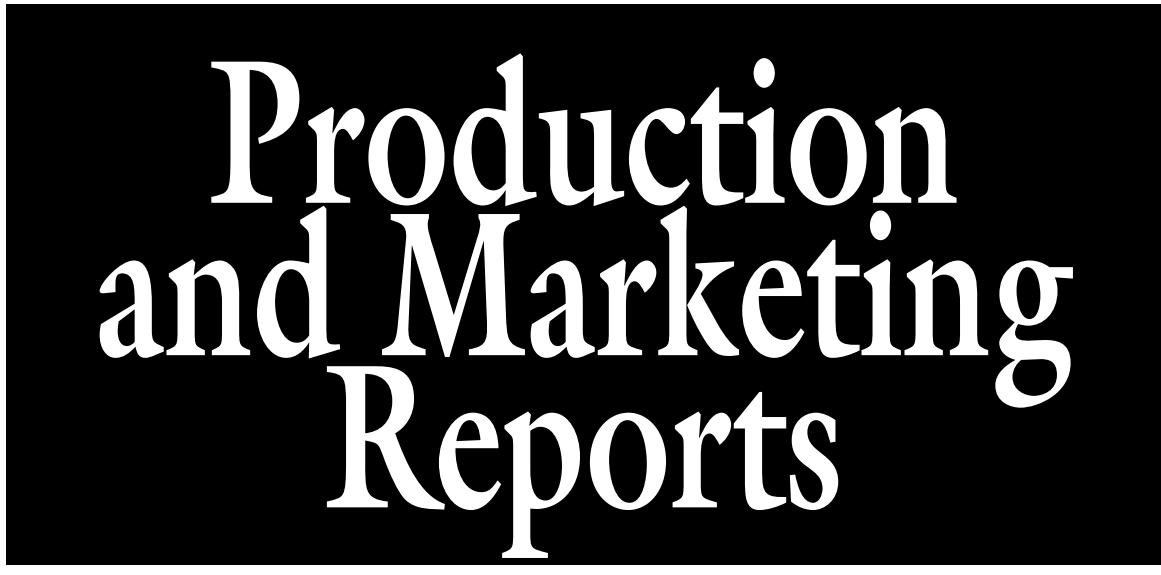

\title{
Caladium Growth Control with Flurprimidol, Paclobutrazol, and Uniconazole
}

\author{
Brian A. Krug ${ }^{1}$, Brian E. Whipker, and Ingram McCall
}

Additional index words. Piccolo, plant growth retardants, Topflor, Sumagic

SuMmary. Flurprimidol preplant tuber soaks $\left(1.25\right.$ to $\left.40 \mathrm{mg} \cdot \mathrm{L}^{-1}\right)$ and substrate drenches $(0.25$ to $4 \mathrm{mg} /$ pot a.i.) were applied to 'Red Flash' caladium (Caladium bicolor) plants for growth control. Flurprimidol was compared with the industry recommendations of paclobutrazol preplant tuber soaks $\left(2.5\right.$ to $\left.40 \mathrm{mg} \cdot \mathrm{L}^{-1}\right)$ and paclobutrazol and uniconazole substrate drenches $(0.25$ to $4 \mathrm{mg} /$ pot a.i. $)$. At the concentrations used, neither flurprimidol nor paclobutrazol preplant tuber soaks controlled plant height or diameter. Longer soaking time or higher concentrations of flurprimidol and paclobutrazol may be required for growth control of vigorous caladium cultivars. Uniconazole substrate drenches did not provide height or diameter control. Both flurprimidol and paclobutrazol substrate drenches at $2 \mathrm{mg} /$ pot a.i. provided acceptable height control resulting in plants that were $17 \%$ and $15 \%$, respectively, shorter than the untreated control. The $4 \mathrm{mg} / \mathrm{pot}$ a.i. drench of flurprimidol or paclobutrazol provided excessive control.

$\mathrm{C}$ aladiums can be excessively large relative to the container in which they are grown, and plant growth regulators (PGRs) are required for height control. No industry standard has been set for optimal height of caladiums, but plants 25 to $28 \mathrm{~cm}$ tall (excluding the pot) would be considered commercially acceptable (Barrett et al., 1995). Paclobutrazol (Bonzi; Syngenta, Greensboro, N.C.) substrate drench recommendations vary from $8 \mathrm{mg} \cdot \mathrm{L}^{-1}$ (Dole and Wilkins, 2005), 0.5 to $1 \mathrm{mg} /$ pot a.i. (Barrett et al.,

Department of Horticultural Science, Box 7609, North Carolina State University, 227C Kilgore Hall, NCSU Box 7609, Raleigh, NC 27695-7609

Use of trade names in this publication does not imply endorsement of products named nor criticism of similar ones not mentioned.

We thank Berger for the root substrates, Scotts for the fertilizer, Dillen Products for the pots, and SePRO Co. for grant support.

${ }^{1}$ Corresponding author. E-mail: bakrug@unity.ncsu.edu.
1995), or 3 to $4 \mathrm{mg}$ /pot a.i. (Wilfret, 1993). All drenches are applied when new growth emerges through the top of the substrate. Wilfret (1993) reported substrate drenches of uniconazole (Sumagic; Valent USA, Marysville, Ohio) at 1 to $2 \mathrm{mg} /$ pot a.i. also were effective. Dole and Wilkins (2005) recommend foliar sprays of daminozide (B-Nine; Chemtura Corp., Middlebury, Conn.) at $2500 \mathrm{mg} \cdot \mathrm{L}^{-1}$, applied up to three times, at 5- to 7-d intervals beginning after the leaves have emerged and fully expanded.
Preplant bulb PGR soaks have been shown to be an effective method of controlling height in a number of other bulb crops, including hyacinths, lilies, narcissus, and tulips (Krug et al., 2005a, 2005b, 2005c, 2006). Preplant tuber soaks of paclobutrazol or uniconazole at a concentration of $5 \mathrm{mg} \cdot \mathrm{L}^{-1}$ on de-eyed tubers were shown to retard overall foliage height (Wilfret, 1993). Flurprimidol (Topflor; SePRO Corp., Carmel, Ind.) has been available in Europe for more than 20 years as a $1.5 \%$ formulation and is being introduced into the U.S. market as a $0.38 \%$ formulation, but commercial dose recommendations for caladiums are not available. Therefore, this study was conducted to determine the efficacy of flurprimidol preplant tuber soaks and substrate drenches on caladiums.

\section{Materials and methods}

Dormant tubers of 'Red Flash' caladiums were de-eyed (removal of apical dominance) as described by Dole and Wilkins (2005) on 17 Mar. 2003. The tubers were potted in 6-inch-diameter round plastic pots with a volume of 2.0 quart on 18 Mar. 2003 with two tubers per pot. The root substrate was Berger BM 6 (Berger Peat Moss, St. Modeste, Quebec), which contained $75 \%$ to $80 \%$ Canadian sphagnum peat and $20 \%$ to $25 \%$ perlite. Pots were held in the greenhouse under black plastic to maintain a temperature of 73 to $75{ }^{\circ} \mathrm{F}$ and high humidity. Plants remained under the black plastic until shoots emerged. As shoot emerged, pots were individually moved to greenhouse benches. Plants were fertilized at each watering with 150 $\mathrm{mg} \cdot \mathrm{L}^{-1} \mathrm{~N}$ from $15 \mathrm{~N}-2.1 \mathrm{P}-12.5 \mathrm{~K}$ fertilizer. Greenhouse set points were $75^{\circ} \mathrm{F}$ day $/ 64^{\circ} \mathrm{F}$ night. Plants were grown under natural daylength.

Plant growth regulator TREATMENTS. On 18 Mar. 2003, preplant tuber soaks were applied for

\begin{tabular}{llll}
\hline $\begin{array}{l}\text { Units } \\
\text { To convert U.S. to SI, } \\
\text { multiply by }\end{array}$ & U.S. unit & SI unit & $\begin{array}{l}\text { To convert SI to U.S., } \\
\text { multiply by }\end{array}$ \\
\hline 29.5735 & $\mathrm{fl} \mathrm{oz}$ & $\mathrm{mL}$ & 0.0338 \\
2.5400 & inch $(\mathrm{es})$ & $\mathrm{cm}$ & 0.3937 \\
28,350 & $\mathrm{oz}$ & $\mathrm{mg}$ & $3.5274 \times 10^{-5}$ \\
1 & $\mathrm{ppm}$ & $\mathrm{mg} \cdot \mathrm{L}^{-1}$ & 1 \\
0.9464 & $\mathrm{qt}$ & $\mathrm{L}$ & 1.0567 \\
$\left({ }^{\circ} \mathrm{F}-32\right) \div 1.8$ & ${ }^{\circ} \mathrm{F}$ & ${ }^{\circ} \mathrm{C}$ & $\left(1.8 \times{ }^{\circ} \mathrm{C}\right)+32$
\end{tabular}


10-min: flurprimidol $(0.38 \%)$ at 1.25 , $2.5,5,10,20$, or $40 \mathrm{mg} \cdot \mathrm{L}^{-1}$; or paclobutrazol (Piccolo; Fine America, Walnut Creek, Calif.) at 2.5, 5, 10, 20 , and $40 \mathrm{mg} \cdot \mathrm{L}^{-1}$. The substrate drench treatments were applied when plant shoots were 2.5 to $5 \mathrm{~cm}$ long on 18 Apr. Substrate drenches were applied at $4 \mathrm{fl} \mathrm{oz}$ per pot: flurprimidol, paclobutrazol, and uniconazole at 0.25 , $0.5,1,2$, or $4 \mathrm{mg} /$ pot a.i. Untreated controls were also included. The experiment was a completely randomized design with six single-plant replications for each of the 27 treatments. On 15 May, plant height (measured from the pot rim to the uppermost part of the plant) and plant diameter (measured at the widest dimension, turned $90^{\circ}$, and averaged) were recorded.

Data ANALYsis. Data were tested by analysis of variance using general linear model (SAS Institute, Cary, N.C.). Plant heights and diameters were regressed using the PROC REG to determine the best-fit, linear, or quadratic model. Terms of the model were evaluated for significance based on a comparison of $\mathrm{F}$ values at $\alpha=$ 0.05 .

\section{Results and discussion}

Preplant Tuber Soaks. 'Red Flash' caladium plants were unaffected by any concentration of flurprimidol or paclobutrazol as preplant tuber soaks (data not presented). Previous research has shown that flurprimidol preplant soaks are effective in controlling height of other bulb crops such as tulips, hyacinths, narcissus, and lilies (Krug et al., 2005a, 2005 b, 2005c, 2006). However, no preplant tuber soak information for caladiums exists for flurprimidol. Label recommendations for paclobutrazol (Bonzi) suggest soaking the tubers for $30 \mathrm{~min}$ in a $60-\mathrm{mg} \cdot \mathrm{L}^{-1}$ solution, but growers prefer treatments that take a shorter amount of time and longer soaking times are not suitable as a result of the increased risk of spreading bacterial disease. Commercial grower recommendations suggested a 10 -min soak at 10 to $15 \mathrm{mg} \cdot \mathrm{L}^{-1}$ paclobutrazol to control height of 'Red Flash' (T. CantwellBates, personal communication). Further research is needed to determine if longer soak duration or higher concentrations will control growth of this vigorous cultivar.
Substrate DRenches. Uniconazole did not control plant height or diameter at concentrations trialed (data not presented). According to the product label, concentrations for uniconazole substrate drenches on herbaceous foliage plants are 0.1 to $1 \mathrm{mg} \cdot \mathrm{L}^{-1}$. Concentrations of uniconazole used in this study were 0.25 to $4 \mathrm{mg}$ /pot a.i., which was equivalent to 2.1 to $33.8 \mathrm{mg} \cdot \mathrm{L}^{-1}$, which was greater than the highest labelrecommended concentration. Results from this study are in disagreement with uniconazole recommendations of 1 to $2 \mathrm{mg} /$ pot a.i. by Wilfret (1993). Uniconazole typically has a two to four times greater efficacy than paclobutrazol at the same dose concentration for many floriculture crops (Whipker and Hammer, 1997). Caladiums appear to be the exception; requiring a greater concentration of uniconazole than paclobutrazol to control growth, as also reported by Barrett et al. (1995).

Paclobutrazol substrate drenches resulted in shorter plants at concentrations $1 \mathrm{mg} /$ pot a.i. or greater and smaller diameters at concentrations $2 \mathrm{mg} /$ pot a.i. or greater (Fig. lA). Both relationships were linear and resulted in plants that were $8 \%$ shorter or greater and $10 \%$ smaller or greater in diameter than the untreated control. Paclobutrazol at a concentration of $2 \mathrm{mg} /$ pot a.i. was two to four times greater than the 0.5 to $1 \mathrm{mg} /$ pot a.i. concentration recommended by Barrett et al. (1995) but 33\% to $50 \%$ less than concentrations recommended by Wilfret (1993). However, 'Red Flash' may be more vigorous than cultivars Aaron, White Christmas, and Carolyn Wharton used by Barrett et al. (1995). A concentration of $2 \mathrm{mg} /$ pot a.i. paclobutrazol is equivalent to $17 \mathrm{mg} \cdot \mathrm{L}^{-1}$, which was more than twice the concentration recommended by Dole and Wilkins (2005). However, no drench volume was recommended that could account for the difference.

The relationship of flurprimidol concentration to plant height was linear (Fig. 1B). Plants were significantly shorter when treated with $2 \mathrm{mg} /$ pot a.i. or greater, which resulted in $17 \%$ shorter plants than the untreated control. Plant diameters were $21 \%$ smaller than the untreated control when treated with $4 \mathrm{mg} /$ pot a.i. flurprimidol. When compared
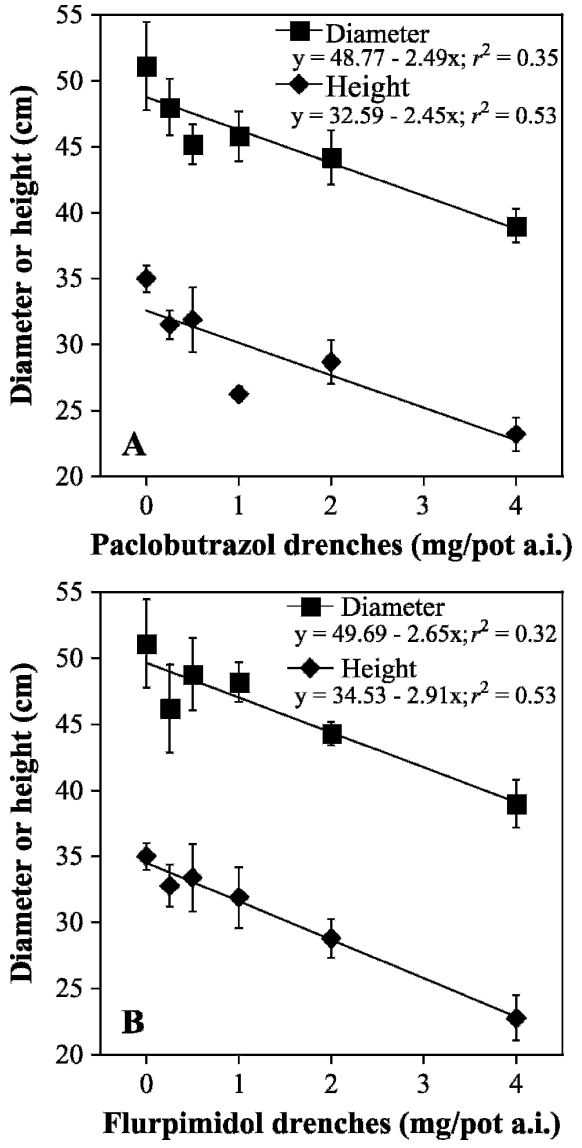

Fig. 1. Effects of (A) paclobutrazol and (B) flurprimidol substrate drenches on 'Red Flash' caladium plant height and diameter $(1 \mathrm{~cm}=0.3937$ inch; $\left.1 \mathrm{mg}=3.5274 \times 10^{-5} \mathrm{oz}\right)$. Error bars represent $S E$ of the mean, $n=6$.

with paclobutrazol, the response of 'Red Flash' caladium plants to flurprimidol substrate drenches produced similar results.

\section{Conclusions}

Longer soaking time or higher concentrations of flurprimidol and paclobutrazol need to be studied to determine the optimal preplant bulb soak concentration for growth control of vigorous caladium cultivars. Substrate drenches of uniconazole were cost-prohibitive on this vigorous caladium cultivar as a result of the high concentrations that would be needed to control height and diameter. Both flurprimidol and paclobutrazol substrate drenches of $2 \mathrm{mg} /$ pot a.i. provided acceptable height control for the vigorous 'Red Flash' cultivar resulting in $17 \%$ and $15 \%$, respectively, shorter plants than the untreated control. Flurprimidol 


\section{Production and Marketing Reports}

and paclobutrazol at $4 \mathrm{mg} /$ pot a.i. provided excessive control, resulting in plants that were too compact and had distorted leaves. Based on this research, the efficacy of flurprimidol is comparable to equal concentrations of paclobutrazol when applied as a substrate drench on 'Red Flash' caladiums.

\section{Literature cited}

Barrett, J., C.A. Bartuska, and T.A. Nell. 1995. Caladium height control with paclobutrazol drench applications. HortScience 30:549-550.
Dole, J.M. and H.F. Wilkins. 2005. Caladium, p. 343-348. Floriculture principles and species. Prentice Hall, Upper Saddle River, N.J.

Krug, B.A., B.E. Whipker, and I. McCall 2005a. Flurprimidol is effective at controlling height of 'Star Gazer' oriental lily. HortTechnology 15:373-376.

Krug, B.A., B.E. Whipker, I. McCall, and J.M. Dole. 2005b. Comparison of flurprimidol to ethephon, paclobutrazol, and uniconazole for hyacinth height control. HortTechnology 15:1-3.

Krug, B.A., B.E. Whipker, I. McCall, and J.M. Dole. 2005c. Comparison of flurprimdiol to ancymidol, paclobutrazol, uniconazole for tulip height control. HortTechnology 15:370-373.

Krug, B.A., B.E. Whipker, I. McCall, and J.M. Dole. 2006. Narcissus response to plant growth regulators. Hort Technology 16:129-132.

Whipker, B.E. and P.A. Hammer. 1997. Efficacy of ancymidol, paclobutrazol, and uniconazole on growth of tuberousrooted dahlias. HortTechnology 7:269272.

Wilfret, G.J. 1993. Caladium, p. 335-347. In: A. DeHertogh and $M$. LeNard (eds.). The physiology of flower bulbs. Elsevier, Amsterdam, The Netherlands. 